\title{
Повторні операціі та операціі для попередження тромбозу у хворих з цукровим діабетом та критичною ішемією нижньої кінцівки
}

\author{
С. М. Діденко
}

Клінічна лікарня «Феофанія», м. Київ

\section{Reoperations and operations, preventing thrombosis, in patients, suffering diabetes mellitus and critical ischemia of lower extremity}

\author{
S. M. Didenko
}

Clinical Hospital «Feofaniya», Kyiv

\section{Реферат}

Мета. Визначити ефективність повторних операцій та операцій для попередження тромбозу у хворих з цукровим діабетом (Цд) та хронічною критичною ішеміею нижньої кінцівки (ХКІНК), порівнявши їх результати.

Матеріали і методи. Узагальнено досвід лікування 439 хворих з ЦД та ХКІНК і стенотично-оклюзійним ураженням (СОУ) артерій підколінно-гомілкового сегмента в Клінічній лікарні «Феофанія» Державного управління справами, Інституті загальної та невідкладної хірургії імені В. Т. Зайцева НАМН України та Київській міській клінічній лікарні № 1 з 1999 по 2016 р., яким виконали відкриті, ендоваскулярні та гібридні реконструктивні операції на артеріях нижніх кінцівок (НК) з метою покращення кровопостачання та усунення проявів ХКІНК. Вік паціентів коливався від 56 до 88 років, у середньому становив $(67,9 \pm 8,1)$ року. Чоловіків було 265 (60,4\%), жінок - 174 (39,6\%).

Результати. 3 огляду на високу частоту ампутації після повторних реконструктивних операцій - 24,6\%, ми запропонували алгоритм обстеження хворих після первинної операції з урахуванням наявності у них факторів ризику СОУ і тромбозу в зоні артеріальної реконструкції (ЗАР) та шляхах припливу і відтоку. На підставі розробленого алгоритму сформульовані показання до виконання операцій для попередження тромбозу, результати яких кращі за результати повторних операцій.

Висновки. Кумулятивна частота збереження кінцівки після повторних операцій через 1 та 3 роки становила 75,4 і 49,2\% відповідно. У зв'язку з високою частотою ампутації після повторних реконструктивних операцій запропоновано алгоритм післяопераційного обстеження хворих з урахуванням наявності у них факторів ризику СОУ і тромбозу в шляхах припливу і відтоку та ЗАР. Періодичність і методи обстеження хворих після виконання первинних реваскуляризуючих операцій повинні грунтуватись на визначенні факторів ризику розвитку післяопераційних ускладнень. Такий комплекс діагностичних заходів дає можливість своєчасно виявити розвиток СОУ в артеріях припливу та відтоку і безпосередньо в ЗАР, що передують виникненню тромбозу, та призначити операцію для попередження тромбозу. Операції для попередження тромбозу забезпечують не лише профілактику тромбозу ЗАР, а й клінічне поліпшення, яке спостерігали у 96,6\% пацієнтів, тоді як після повторних операцій - у 58,5\% пацієнтів. Кумулятивна частота збереження кінцівки після операцій для попередження тромбозу через 1 та 3 роки становила відповідно 98,3 і 91,5\%, що значно перевищує аналогічні показники після повторних операцій.

Ключові слова: цукровий діабет; ішемічна форма синдрому діабетичної стопи; хронічна критична ішемія нижніх кінцівок; ендоваскулярна операція; гібридна операція; повторна операція; операція для попередження тромбозу.

\section{Abstract}

Objective. To determine the efficacy of reoperations and the thrombosis-preventive operations in patients with diabetes mellitus (DM) and chronic ischemia of the lower extremity (CHILE), comparing their results.

Materials and methods. There was summarized the experience of treatment of 439 patients, suffering DM and CHILE with stenoticocclusion affection (SOA) of the popliteo-tibial segment arteries in the Clinical Hospital «Feofaniya» of State Directorate for Affairs, Institute of General and Urgent Surgery named after V. T. Zaytsev NAMS of Ukraine and the Kyiv's Municipal Clinical Hospital № 1 in $1999-$ 2016 yrs, to whom the open, endovascular and hybrid reconstructive operations on the lower extremities arteries were performed with the objective to improve the blood supply and elimination of the CHILE signs. The patients' age was between 56 and 88 years old, and have constituted $(67.9 \pm 8.1)$ yrs old at average. There were $265(60.4 \%)$ men and $174(39.6 \%)$ women.

Results. Taking into account a high rate of the amputation conduction after second performance of reconstructive interventions - $24.6 \%$, we proposed the examination algorithm for patients after primary operation, concerning the presence of the risk factors in them for the SOA and thrombosis occurrence in the arterial reconstruction zone (ARZ) and the ways of inflow and outflow. Basing on the algorithm elaborated, the indications were formulated for performance of operations, preventing thrombosis, results of which are better than those of reoperations.

Conclusion. Cumulative rate of the extremity preservation after reoperations in 1 and 3 years have constituted 75.4 and $49.2 \%$ accordingly. Taking into account a high rate of amputations performance after repeated reconstructive operations, the algorithm was proposed for the patients' postoperative examination, depending on presence of the risk factors in them for the SOA and thrombosis occurrence on the ways of inflow and outflow and ARZ. Periodicity and methods of examination of the patients after performance of primary revascularization operations must be based on determination of the risk factors for the development of postoperative complications. Such a complex of diagnostic measures gives possibility to reveal a development of SOA in the inflow and the outflow arteries and immediately in ARZ, which precedes the thrombosis occurrence, and to administer the antithrombotic operation. The preventing thrombosis operations provide not only the ARZ thrombosis prophylaxis, but a clinical improvement as well, what was observed in $96.6 \%$ patients, while after reoperations - in 58.5\% patients. Cumulative rates of the extremity preservation, after operations for the thrombosis prevention in 1 and 3 years, have constituted, accordingly, 98.3 and $91.5 \%$, what significantly surpasses the analogous indices after reoperations.

Keywords: diabetes mellitus; ischemic form of the diabetic foot syndrome; chronic critical ischemia of the lower extremities; endovascular operation; hybridic operation; reoperation; operation, preventing thrombosis. 
Результати хірургічного лікування СОУ аорто-клубового і стегново-підколінного сегментів, яке призводить до розвитку ХКІНК, за останні десятиліття постійно поліпшуються [1, 2]. Проте результати реконструктивних операцій на артеріях підколінно-гомілково-стопового сегмента досі залишаються невтішними, особливо у хворих з Цд та ХКІНК [3]. Тривають дискусії щодо підходів у лікуванні хворих з поєднаним ураженням поверхневої стегнової артерії (ПСА) та артерій підколінно-гомілково-стопового сегмента [4]. Запропоновано велику кількість методів оперативних втручань на артеріях підколінно-гомілково-стопового сегмента, але немає чітких показань до кожного з них, у виборі тактики та техніки операцій наявні значні розбіжності [5, 6]. Остаточно не вирішено питання динамічного спостереження за пацієнтами в післяопераційному періоді [7] та не розроблені показання до виконання операцій для попередження тромбозу у разі розвитку стенозу ЗАР або погіршення стану шляхів припливу чи відтоку, а також до виконання повторних реконструкцій у разі тромбозу ЗАР у післяопераційному періоді [8].

Мета дослідження: вивчити ефективність повторних операцій та операцій для попередження тромбозу у хворих з ЦД та ХКІНК, порівнявши їх результати.

\section{Матеріали і методи дослідження}

Узагальнено досвід лікування 439 хворих з Цд та ХКІНК і СОУ артерій підколінно-гомілкового сегмента в Клінічній лікарні «Феофанія» Державного управління справами, Інституті загальної та невідкладної хірургії імені В. Т. Зайцева НАМН України та Київській міській клінічній лікарні № 1 з 1999 по 2016 р., яким виконали відкриті, ендоваскулярні та гібридні реконструктивні операціі на артеріях НК з метою покращення кровопостачання та усунення проявів ХКІНК.

Вік пацієнтів коливався від 56 до 88 років, у середньому становив $(67,9 \pm 8,1)$ року. Чоловіків було 265 (60,4\%), жінок - 174 (39,6\%). В анамнезі захворюваність на џД понад 10 років констатована у 68,1\% хворих. Під час госпіталізації у 59,5\% пацієнтів ЦД мав декомпенсований характер.

Хворих розподілили на дві групи. Групу А склали 164 пацієнти з ураженням артерій підколінно-гомілкового сегмента в поєднанні з СОУ ПСА, групу Б - 275 пацієнтів, у яких діагностовано ізольоване СОУ артерій підколінногомілкового сегмента. За характером виконаних оперативних втручань пацієнтів групи А було розподілено на три підгрупи: А1 - 61 хворий, якому виконали ізольовану реконструкцію ПСА, А2 - 38 хворих, яким виконали дворівневу відкриту артеріальну реконструкцію; А3 - 65 хворих, яким виконали гібридну артеріальну реконструкцію; пацієнтів групи Б - на дві підгрупи: Б1 - 126 хворих, яким виконали відкриту реконструкцію артерій з формуванням дистального анастомоза на рівні гомілкових або стопових артерій, Б2 - 149 хворих, яким виконали балонну ангіопластику (БАП) артерій підколінно-гомілковостопового сегмента.

Діагностику проводили за таким алгоритмом: анамнез, клінічне та лабораторне обстеження: тривалість захворювання, переміжна кульгавість, біль у стані спокою, наяв- ність і характер некрозу, наявність пульсації на магістральних артеріях, вивчення лабораторних показників та перебігу супутніх захворювань; неінвазивне обстеження: визначення індексу регіонарного систолічного тиску (IРCT) на артеріях стопи за допомогою портативного ультразвукового апарата «SuperDopplex» (Китай), ультразвукова доплерографія (УЗДГ) судин НК за допомогою апарата «Flexfocus» («BKMedical», Данія), ультразвукове дослідження серця та артерій каротидного басейну за допомогою апарата «EUB 7500» («Hitachi», Японія), визначення парціального тиску кисню $\left(\mathrm{TcpO}_{2}\right)$ у тканинах стопи за допомогою апарата «ТСM-4 Series» («Radiometer Copenhagen», Данія); інвазивне обстеження: ангіографія із застосуванням мобільної ангіографічної системи «Euroampli ALIEN» («EUROCOLUMBUS SRL», Італія) та ангіографічної системи «Integris Allura» («Philips», Нідерланди).

У 156 хворих верифікували прохідність ПСА за допомогою УЗДГ, їм виконали ангіографію за запропонованою методикою (Пат. України № 114970 «Спосіб ангіографічного дослідження артерій нижньої кінцівки у хворого на ішемічну форму синдрому стопи діабетика»), яка полягає у виконанні рентгенконтрастної ангіографії артерій підколінно-гомілково-стопового сегмента та відрізняється тим, що для введення контрастної речовини здійснюють пункцію ПСА у їі верхній третині.

\section{Результати}

Протягом періоду спостереження, який становив у середньому 12 міс, після 439 первинних операцій виконали 65 (14,8\%) повторних операцій, які умовно розподілили на три варіанти: перший - тромбектомія із зони реконструкції з усуненням причин тромбозу за допомогою ендоваскулярних методів; другий - реконструкція дистального або проксимального анастомоза первинного шунта або подовження первинного шунта новим шунтом в обхід одного з анастомозів; третій - шунтування з повним обходом ЗАР новим шунтом. Якщо була можливість виконати тромбектомію, перевагу віддавали першому варіанту; за відсутності умов для виконання тромбектомії - другому або третьому варіанту, якщо в процесі ревізії шунта вдавалося виконати тромбектомію тільки з одного анастомоза - другому варіанту; якщо в процесі ревізії не вдавалося виконати тромбектомію із зони раніше виконаної ангіопластики або з обох анастомозів шунта, неможливо було відновити прохідність зони реконструкції ендоваскулярними методами - третьому варіанту (табл. 1).

Протягом періоду спостереження із 65 хворих, у яких виник тромбоз ЗАР, 16 (24,6\%) виконана висока ампутація НК. 3 огляду на велику частоту ампутації після повторних реконструктивних операцій, ми запропонували алгоритм обстеження хворих після первинної операції з урахуванням наявності у них факторів ризику розвитку СОУ і тромбозу ЗАР та в шляхах припливу і відтоку.

На нашу думку, розвиток тромбозу ЗАР найбільш вірогідний у хворих, які мають фактори ризику (табл. 2).

За сумарною кількістю балів, якою було оцінено наявні у хворого фактори ризику розвитку тромбозу ЗАР, визначали тактику його обстеження в післяопераційному періоді. Якщо сума балів була менше 10, вважали ризик тром- 


\begin{tabular}{|c|c|c|c|c|c|c|c|}
\hline \multirow{3}{*}{ Підгрупа } & \multirow{3}{*}{$\begin{array}{l}\text { Число } \\
\text { хворих }\end{array}$} & \multirow{2}{*}{\multicolumn{2}{|c|}{$\begin{array}{l}\text { Частота } \\
\text { тромбозу } \\
\text { ЗАР }\end{array}$}} & \multicolumn{2}{|c|}{ Втручання } & \multicolumn{2}{|c|}{ Число хворих, } \\
\hline & & & & \multirow{2}{*}{ на стегновому сегменті } & \multirow{2}{*}{$\begin{array}{l}\text { на артеріях підколінно- } \\
\text { гомілкового сегмента }\end{array}$} & \multirow{2}{*}{$\begin{array}{l}\text { яким відновили } \\
\text { кровообіг }\end{array}$} & \multirow{2}{*}{$\begin{array}{c}\text { яким виконали } \\
\text { високу } \\
\text { ампутацію }\end{array}$} \\
\hline & & абс. & $\%$ & & & & \\
\hline \multirow{2}{*}{ A1 } & \multirow{2}{*}{61} & \multirow{2}{*}{21} & \multirow{2}{*}{34,4} & \multirow{2}{*}{$\begin{array}{c}\text { Тромбектомія, реконструкція } \\
\text { анастомозів (7); } \\
\text { решунтування (5) }\end{array}$} & Тромбектомія і БАП (10) & 8 & 2 \\
\hline & & & & & Тромбектомія (11) & 4 & 7 \\
\hline $\mathrm{A} 2$ & 38 & 4 & 10,5 & $\begin{array}{c}\text { Тромбектомія, реконструкція } \\
\text { анастомозів (3) }\end{array}$ & Тромбектомія (4) & 2 & 1 \\
\hline A3 & 65 & 12 & 18,5 & $\begin{array}{c}\text { Тромбектомія, реконструкція } \\
\text { анастомозів (4); } \\
\text { решунтування (3) }\end{array}$ & Тромбектомія і БАП (12) & 10 & 2 \\
\hline Б1 & 126 & 7 & 5,6 & - & $\begin{array}{c}\text { Тромбектомія, } \\
\text { реконструкція } \\
\text { анастомозів (5); } \\
\text { решунтування (2) }\end{array}$ & 5 & 2 \\
\hline 52 & 149 & 21 & 14,1 & - & Тромбектомія і БАП (21) & 19 & 2 \\
\hline
\end{tabular}

\begin{tabular}{|c|c|c|c|}
\hline \multicolumn{4}{|c|}{ Фактори ризику розвитку тромбозу ЗАР } \\
\hline \multirow{2}{*}{ Фактори ризику } & \multicolumn{3}{|c|}{ Кількість балів } \\
\hline & 0 & 1 & 2 \\
\hline $\begin{array}{l}\text { Ступінь периферичного опору } \\
\text { (за R. B. Rutherford і співавторами, 1997) }\end{array}$ & менше 5 & від 5 до 7 & від 8 до 10 \\
\hline Паління & не палив & кинув & продовжує \\
\hline Індекс маси тіла & менше 30 & $30-40$ & більше 40 \\
\hline Інфаркт міокарда та/або інсульт в анамнезі & не було & один епізод & $\begin{array}{l}\text { більше одного } \\
\text { епізоду }\end{array}$ \\
\hline Стать & - & жінки & чоловіки \\
\hline Цукровий діабет & компенсація & субкомпенсація & декомпенсація \\
\hline Миготлива аритмія & немає & корегована & некорегована \\
\hline Ступінь тяжкості діабетичної мікроангіопатії & легкий & середньої тяжкості & тяжкий \\
\hline Тромбоз ЗАР у ранньому післеопераційному періоді & не було & - & був \\
\hline Виконана реконструктивна операція & - & $\begin{array}{l}\text { в межах одного } \\
\text { артеріального } \\
\text { сегмента }\end{array}$ & $\begin{array}{c}\text { багаторівнева або } \\
\text { гібридна артеріальна } \\
\text { реконструкція }\end{array}$ \\
\hline Ампутація в анамнезі & не було & в межах стопи & висока \\
\hline
\end{tabular}

бозу в післяопераційному періоді низьким та призначали такі дослідження: визначення ІРСТ і контрольна УЗДГ через 3, 6, 12 міс, далі - 2 рази на рік. Якщо сума балів була 11 - 16, вважали ризик тромбозу в післяопераційному періоді середнім та призначали такі дослідження: визначення IPCT і контрольна УЗДГ 4 рази на рік. Якщо сума балів була 17 - 22, вважали ризик тромбозу в післяопераційному періоді високим та призначали такі дослідження: визначення IPCT і контрольна УЗДГ кожні 3 міс та через 6 міс контрольна ангіографія, далі - 1 раз на рік контрольна ангіографія.

Якщо за даними ультразвукових методів виявляли ознаки СОУ в ЗАР або артеріях припливу чи відтоку, призначали ангіографічне дослідження.

До СОУ, які були предметом обов'язкової хірургічної корекції для попередження тромбозу, відносили: зміни ЗАР (стеноз шунта, області ендартеректомії або ангіопластики більше 60\%, аневризматичні розширення аутовенозного шунта чи анастомозів); зміни анастомозів (стеноз більше 60\%, аневризматичні розширення); стеноз більше 60\% або оклюзія в шляхах припливу, що призводило до зменшення перфузійного тиску і швидкості кровотоку в ЗАР; сте- ноз більше 60\% або оклюзія артерій сприймаючого русла, що призводило до збільшення периферичного опору.

Протягом періоду спостереження 59 пацієнтам після первинних артеріальних реконструкцій, у тому числі ендоваскулярних і гібридних, були виконані операції для попередження тромбозу: у зв'язку зі змінами ЗАР - 32 (54,2\%), СОУ артерій припливу - 9 (15,3\%), СОУ артерій відтоку - 18 (30,5\%). У 28 (47,5\%) пацієнтів СОУ, які виникли в післяопераційному періоді та потребували втручання для попередження тромбозу, не супроводжувалися клінічними проявами і були виявлені під час скринінгу. У 31 (52,5\%) пацієнта спостерігали симптоми артеріальної недостатності. Пацієнти, яким була виконана операція для попередження тромбозу, мали фактори ризику розвитку тромбозу ЗАР, оцінені в середньому в $(17,8 \pm 3,2)$ бала, тобто у них був високий ризик розвитку тромбозу ЗАР у післяопераційному періоді.

Із 59 пацієнтів, яким виконали операції для попередження тромбозу, 37 (62,7\%) оперовані ендоваскулярним методом, 12 (20,3\%) виконано відкрите хірургічне втручання і 10 (17\%) - гібридну реконструкцію. Жоден пацієнт на госпітальному етапі не помер. Із загальних ускладнень в ран- 
ньому післяопераційному періоді лише у 1 (1,7\%) хворого розвинувся гострий інтрамуральний інфаркт міокарда без серцевої недостатності. Хворий виписаний у задовільному стані. Високу ампутацію у зв'язку з повторною емболізацією дистального артеріального русла НК з розвитком критичної ішемії внаслідок пароксизмів фібриляції передсердь виконали 1 (1,7\%) хворому.

Попереджувальні операції забезпечують не лише профілактику тромбозу ЗАР, а й поліпшення як клінічних показників, так і показників регіонарної гемодинаміки (достовірне збільшення IPCT). Безпосередні результати попереджувальних операцій значно краще результатів повторних реконструкцій. Якщо після повторних операцій 24,6\% хворих виконали високу ампутацію НК, то після попереджувальних операцій погіршення спостерігали лише у 2 (3,4\%) хворих, а високу ампутацію виконали 1 (1,7\%) хворому. Після повторних операцій клінічне поліпшення констатували у 58,5\% пацієнтів, після попереджувальних - у 96,6\%.

Кумулятивна частота збереження кінцівки через 1 і 3 роки становила відповідно 98,3 і 91,5\%, що значно перевищує аналогічні показники після повторних реконструктивних операцій - 75,4 і 49,2\%.

\section{Обговорення}

Запорукою уникнення пізніх ускладнень, таких як СОУ в ЗАР та шляхах припливу і відтоку та, як наслідок, тромбозу ЗАР є своєчасне обстеження оперованих хворих і, за потреби, виконання втручань для попередження тромбозу. Найбільш доступним і безпечним методом діагностики є УЗДГ, яка дозволяла визначити пікову систолічну швидкість кровотоку, виявити стеноз ЗАР, а також артерій припливу і відтоку. Але найбільш інформативним методом діагностики стану артеріального русла у оперованих хворих, за даними якого встановлювали показання до операції для попередження тромбозу, вважали рентгенконтрастну ангіографію.

Виявлення СОУ до виникнення тромбозу ЗАР i ïх хірургічна корекція приводять не лише до покращення безпосередніх клінічних результатів, а й до значного покращення віддалених результатів первинної реконструктивної операціі. Це стало можливим завдяки регулярним оглядам і обстеженню оперованих хворих згідно з розробленим алгоритмом, а також активній хірургічній тактиці по відношенню до виявлених СОУ, які призводять до виникнення тромбозу ЗАР. Висока складність повторних реконструкцій, їх значно гірші результати стали підставою для розширення показань до виконання операцій для попередження тромбозу за функціонуючої ЗАР. Отже, попереджувальна операція в значно більшій мірі, ніж повторна, подовжує період збереження кінцівки і покращує якість життя оперованих хворих.

\section{Висновки}

1. Кумулятивна частота збереження кінцівки після повторних операцій через 1 і 3 роки становила 75,4 і 49,2\% відповідно. У зв'язку з великою частотою ампутації після повторних реконструктивних операцій запропоновано алгоритм післяопераційного обстеження хворих з огляду на наявність у них факторів ризику розвитку СОУ і тромбозу в шляхах припливу і відтоку та ЗАР.

2. Періодичність і методи обстеження хворих після виконання первинних реваскуляризуючих операцій повинні грунтуватись на визначенні факторів ризику розвитку післяопераційних ускладнень. Такий комплекс діагностичних заходів дає можливість виявити розвиток СОУ в артеріях припливу та відтоку і безпосередньо в ЗАР, що передують виникненню тромбозу, та призначити операцію для попередження тромбозу.

3. Операції для попередження тромбозу забезпечують не лише профілактику тромбозу ЗАР, а й клінічне поліпшення, яке спостерігали у 96,6\% пацієнтів, тоді як після повторних операцій - у 58,5\%. Кумулятивна частота збереження кінцівки після операцій для попередження тромбозу становила через 1 і 3 роки відповідно 98,3 і 91,5\%, що значно перевищує аналогічні показники після повторних операцій.

\section{References}

1. Kireev KA, Fokin AA, Rodnianskiı̌ DV. Hybrid intervention for an atherosclerotic lesion of arteries of the iliofemoral segment. Angiol Sosud Khir. 2018;24(1):156-9. Russian. PMID: 29688209

2. Schürmann K. Aortic bifurcation reconstruction: Endovascular repair and alternatives. Radiologe. 2018 Sep;58(9):829-36. doi: 10.1007/s00117018-0438-9. Review. German. PMID: 30094480

3. Liu G, Cui C, Yin M, Ye K, Liu X, Qin J, et al. Staged endovascular repair of critical limb ischemia in high risk patients: the procedural and clinical outcomes. Int Angiol. 2018 Feb;37(1):52-8. doi: 10.23736/S03929590.17.03840-8. Epub 2017 Sep 7. PMID: 28884985.

4. Takayama T, Matsumura JS. Complete Lower Extremity Revascularization via a Hybrid Procedure for Patients with Critical Limb Ischemia. Vasc Endovascular Surg. 2018 May;52(4):255-61. doi: 10.1177/1538574418761723. Epub 2018 Feb 27. PMID: 29486676

5. Dilaver N, Twine CP, Bosanquet DC. Direct vs. Indirect Angiosomal Revascularisation of Infrapopliteal Arteries, an Updated Systematic Review and Meta-analysis. Eur J Vasc Endovasc Surg. 2018 Aug 24. pii: S1078-5884(18)30444-1. doi: 10. 1016/j.ejvs.2018.07.017. [Epub ahead of print] Review. PMID: 30150071

6. Kazakov YI, Lukin IB, Kazakov AY, Efimov SY, Velikov PG. Choosing the method of reconstruction for lower-limb critical ischemia. Angiol Sosud Khir. 2015;21(2):152-8. Russian. PMID: 26035578.

7. Baumann F, Diehm N. Restenosis after infrapopliteal angioplasty clinical importance, study update and further directions. Vasa. 2013 Nov;42(6):413-20. doi: 10.1024/0301-1526/a000310. Review. PMID: 24220117

8. Almasri J, Adusumalli J, Asi N, Lakis S, Alsawas M, Prokop LJ, et al. A systematic review and meta-analysis of revascularization outcomes of infrainguinal chronic limb-threatening ischemia. J Vasc Surg. 2018 Aug;68(2):624-33. doi: 10.1016/j.jvs.2018.01.066. Epub 2018 May 24. Review. PMID: 29804736 